\title{
Clonidina como Droga Adjuvante no Tratamento da Síndrome de Abstinência Alcoólica em Unidade de Terapia Intensiva. Relato de Caso *
}

\section{Clonidine as Adjuvant Therapy for Alcohol Withdrawal Syndrome in Intensive Care Unit. Case Report}

Leandro Gobbo Braz ${ }^{1}$; Lais Helena Camacho Navarro ${ }^{1}$; José Reinaldo Cerqueira Braz, TSA ${ }^{2}$; Ubirajara Teixeira da Silva ${ }^{3}$; Fábio Akio Yamaguti ${ }^{3}$; José Carlos Cristovan ${ }^{3}$

\section{RESUMO}

Braz LG, Navarro LHC, Braz JRC, Silva UT, Yamaguti FA, Cristovan JC - Clonidina como Droga Adjuvante no Tratamento da Síndrome da Abstinência Alcoólica em Unidade de Terapia Intensiva. Relato de Caso

JUSTIFICATIVA E OBJETIVOS: A sedação de dependentes de álcool e drogas em Unidades de Terapia Intensiva (UTI) é um desafio pela elevada incidência de tolerância às drogas sedativas e da elevada freqüencia de síndromes de abstinência. O objetivo deste relato é mostrar um caso de paciente jovem admitido na UTI que desenvolveu síndrome de abstinência alcoólica e tolerância às drogas sedativas, solucionadas somente após o uso de clonidina.

RELATO DO CASO: Paciente do sexo masculino, 18 anos, dependente de álcool, tabaco, cocaína e maconha, vítima de acidente por arma de fogo, foi admitido na UTI no $1^{\circ}$ dia de pós-operatório de enterectomia, após aspiração de conteúdo gástrico durante reintubação traqueal. Evolução clínica: drogas vasoativas até o $4^{\circ}$ dia de internação $e$ broncopneumonia bilateral com derrame pleural e necessidade de ventilação artificial até o $15^{\circ}$ dia. O esquema de sedação inicial utilizado foi a associação de midazolam e fentanil. A partir do $4^{\circ}$ dia, o paciente apresentou vários episódios de agitação psicomotora, mesmo com a associação de lorazepam no $6^{\circ}$ dia. No $9^{\circ}$ dia, o paciente recebeu as maiores doses dos fármacos, mas permanecia agitado. Optou-se pela associação de dexmedetomidina, que reduziu as doses das outras drogas em $35 \%$ e diminuiu a agitação. No $12^{\circ}$ dia, o midazolam e a dexmedetomidina foram substituídos pela infusão de propofol, com piora do quadro. No $13^{\circ}$ dia, foi associada clonidina ao esquema de sedação, com resolução do quadro de agitação. No $14^{\circ}$ dia, o propofol foi suspenso, sendo mantida a infusão de fentanil e reintroduzida a infusão de midazolam, com doses respectivamente $75 \%$ e $65 \%$

* Recebido do (Received from) CET/SBA do Departamento de Anestesiologia da Faculdade de Medicina de Botucatu (FMB - UNESP), Botucatu, $S P$

1. Pós-Graduando (Mestrado) do Programa de Pós-Graduação em Anestesiologia da FMB - UNESP

2. Professor Titular do CET/SBA Departamento de Anestesiologia da FMB - UNESP

3. Médico da Unidade de Terapia Intensiva do Hospital das Clínicas da FMB - UNESP

Apresentado (Submitted) em 05 de fevereiro de 2003

Aceito (Accepted) para publicação em 22 de abril de 2003

Endereço para Correspondência (Correspondence to)

Dr. Leandro Gobbo Braz

Dept ${ }^{\circ}$ de Anestesiologia da FMB - UNESP

18618-970 Botucatu, SP

(c) Sociedade Brasileira de Anestesiologia, 2003 menores em relação ao pico de uso destas drogas. No $15^{\circ}$ dia, o paciente foi extubado e teve alta da UTI.

CONCLUSÕES: A droga de escolha para o tratamento da síndrome de abstinência alcoólica é o benzodiazepínico. Entretanto, no presente relato, somente o uso adjuvante de clonidina conseguiu proporcionar tratamento adequado ao paciente.

Unitermos: DOENÇAS: síndrome de abstinência alcoólica; DROGAS: $\alpha_{2}$-agonista: clonidina

\section{SUMMARY}

Braz LG, Navarro LHC, Braz JRC, Silva UT, Yamaguti FA, Cristovan JC - Clonidine as Adjuvant Therapy for Alcohol Withdrawal Syndrome in Intensive Care Unit. Case Report

BACKGROUND AND OBJECTIVES: Sedation of patients with past history of alcohol and drug abuse in Intensive Care Units (ICU) is a challenge due to the high incidence of sedative drugs tolerance and withdrawal syndromes. This report aimed at describing a case of a young patient admitted to the ICU who developed alcohol withdrawal syndrome and tolerance to sedatives, resolved only after clonidine administration.

CASE REPORT: Male patient, 18 years old, alcohol, tobacco, cocaine and marijuana abuser, victim of firearm accident, who was admitted to the ICU in the first post-enterectomy day, after gastric content aspiration during tracheal re-intubation. Clinical evolution was: vasoactive drugs up to the $4^{\text {th }}$ day; bilateral bronchopneumonia with pleural effusion and need for artificial ventilation up to the $15^{\text {th }}$ day. Initial sedation scheme was the association of midazolam and fentanyl. As from the $4^{\text {th }}$ day, patient presented with several psychomotor agitation episodes, even after the association of lorazepam in the $6^{\text {th }}$ day. In the $9^{\text {th }}$ day, patient received the largest doses but remained agitated. Dexmedetomidine was associated, which has decreased other drug doses in $35 \%$ and has improved agitation. In the $12^{\text {th }}$ day, midazolam and dexmedetomidine were replaced by propofol infusion with worsening of agitation. In the $13^{\text {th }}$ day, clonidine was associated to the sedation scheme with total resolution of agitation. Propofol was withdrawn in the $14^{\text {th }}$ day, fentanyl was maintained and midazolam infusion was restarted, with doses $75 \%$ and $65 \%$ lower as compared to peak doses of such drugs. Patient was extubated in the $15^{\text {th }}$ day and was discharged from ICU.

CONCLUSIONS: Benzodiazepines should remain the drugs of choice for the treatment of acute alcohol withdrawal syndrome. However in this report, only adjuvant clonidine was able to adequately treat the patient.

Key Words: DISEASES: alcohol withdrawal syndrome; DRUGS, $\alpha_{2}$-agonist: clonidine 


\section{INTRODUÇÃO}

A manutenção de adequado nível de segurança e conforto em pacientes graves é objetivo universal em Unidade de Terapia Intensiva nos casos de utilização de tubos traqueais para manutenção de ventilação artificial quando existir a necessidade do emprego de fármacos sedativos. Porém, a sedação de dependentes de álcool e de outras drogas é um desafio pela alta incidência de tolerância e das síndromes de abstinência fortemente relacionadas aos casos pós-cirúrgicos de trauma e infecção. Inúmeros tratamentos têm sido propostos para as síndromes de abstinência, sendo descritos protocolos monoterápicos, assim como outros em que a associação de drogas adjuvantes, como a clonidina, parece diminuir as falhas de sedação ${ }^{1,2}$

A clonidina, um agonista dos receptores $\alpha_{2}$-adrenérgicos, é cada vez mais utilizada como fármaco adjuvante em anestesias gerais e em bloqueios raquídeos ${ }^{3}$. Seu uso fora da sala de operação começa a ganhar destaque, tanto na medicação pré-anestésica ${ }^{4}$ como no tratamento de distúrbios psiquiátricos e, principalmente dos sintomas de abstinência referentes aos opióides ${ }^{5}$, álcool ${ }^{6}$ ou tabaco ${ }^{7}$, além da possibilidade de seu emprego em ambulatórios no tratamento da destoxificação dessas substâncias.

O objetivo deste relato é mostrar um caso de paciente jovem dependente de álcool e drogas admitido na Unidade de Terapia Intensiva após complicação pós-operatória imediata, que desenvolveu síndrome de abstinência alcoólica e tolerância às drogas sedativas, solucionadas somente após o uso de clonidina.

\section{RELATO DO CASO}

Paciente do sexo masculino, 18 anos, dependente químico de álcool, tabaco, cocaína e maconha, foi submetido à enterectomia de emergência, devido a acidente provocado por arma de fogo. Durante o pós-operatório imediato, na enfermaria, apresentou depressão respiratória após extubação traqueal. Durante as manobras para reintubação traqueal, houve aspiração do conteúdo gastroesofágico regurgitado. Foi admitido na Unidade de Terapia Intensiva no $1^{\circ}$ dia do pós-operatório. O paciente desenvolveu broncopneumonia bilateral e derrame pleural necessitando de drogas vasoativas até o $4^{\circ}$ dia de internação para manutenção dos parâmetros hemodinâmicos, e de ventilação artificial até o $15^{\circ}$ dia com a utilização de elevadas frações inspiradas de oxigênio. Durante todo a internação recebeu reposição eletrolítica adequada e administração de tiamina, vitamina $\mathrm{B}_{12}$ e ácido fólico. Não desenvolveu distúrbio do equilíbrio ácido-base ou eletrolítico.

O esquema de sedação inicialmente utilizado foi a associação de midazolam, na dose de $0,2 \mathrm{mg} \cdot \mathrm{kg}^{-1} \cdot \mathrm{h}^{-1}$, e fentanil, na dose de $3 \mu \mathrm{g} \cdot \mathrm{kg}^{-1} \cdot \mathrm{h}^{-1}$ para obtenção de nível 4 e 5 pela escala de sedação de Ramsay ${ }^{8}$. A partir do $4^{\circ}$ dia, apresentou agitação psicomotora, tremores, taquicardia, hipertensão arterial, sudorese e midríase, necessitando do aumento progressivo das doses das drogas, mas sem melhora do quadro, mesmo com a introdução no $6^{\circ}$ dia de lorazepam por via gástrica, na dose de $4 \mathrm{mg} / \mathrm{dia}$. No $9^{\circ} \mathrm{dia}$, o paciente recebeu as maiores doses dos fármacos: midazolam - 0,28 mg. $\mathrm{kg}^{-1} \cdot \mathrm{h}^{-1}$, fentanil $4,13 \mu \mathrm{g} \cdot \mathrm{kg}^{-1} \cdot \mathrm{h}^{-1}$ e lorazepam- $16 \mathrm{mg} / \mathrm{dia}$, permanecendo com quadro de grande agitação.

No $10^{\circ}$ dia, optou-se pela associação de dexmedetomidina na infusão de 0,6 a $0,8 \mu \mathrm{g} \cdot \mathrm{kg}^{-1} \cdot \mathrm{h}^{-1}$ que, no $11^{\circ} \mathrm{dia}$, na maior dose, reduziu em $35 \%$ as doses dos demais fármacos, com melhora parcial da sintomatologia. No $12^{\circ}$ dia, o midazolam e a dexmedetomidina foram substituídos pela infusão de propofol, na dose de $5 \mathrm{mg} \cdot \mathrm{kg}^{-1} \cdot \mathrm{h}^{-1}$, com leve piora do quadro. No $13^{\circ} \mathrm{dia}$, foi associada clonidina, na dose de $0,15 \mathrm{mg}$ a cada 6 horas por via venosa, ao esquema de sedação com resolução total do quadro de agitação psicomotora e diminuição, em relação ao dia anterior, de $38 \%$ da infusão de propofol e de $42 \%$ da infusão de fentanil. No $14^{\circ}$ dia, a infusão de fentanil foi mantida, enquanto que o propofol foi substituído por midazolam, em doses respectivamente $75 \%$ e $65 \%$ menores em relação ao pico de uso desses fármacos no $9^{\circ} \mathrm{dia}$, permanecendo o paciente adequadamente sedado (Ramsay 4). No $15^{\circ} \mathrm{dia}$, o paciente apresentou critérios para a realização de extubação traqueal e teve alta da Unidade de Terapia Intensiva, com manutenção de clonidina. O esquema de sedação empregado está apresentado na figura 1.

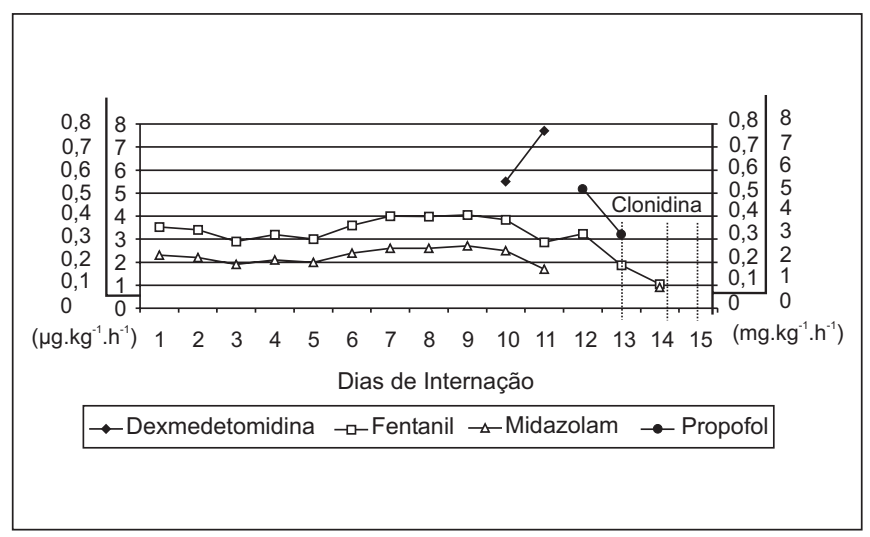

Figura 1 - Esquema de Sedação Empregado durante a Internação: Dexmedetomidina $\left(\mu \mathrm{g} \cdot \mathrm{kg}^{-1} \cdot \mathrm{h}^{-1}\right)$; Fentanil $\left(\mu \mathrm{g} \cdot \mathrm{kg}^{-1} \cdot \mathrm{h}^{-1}\right)$; Midazolam $\left(\mathrm{mg} \cdot \mathrm{kg}^{-1} \cdot \mathrm{h}^{-1}\right)$; Propofol $\left(\mathrm{mg} \cdot \mathrm{kg}^{-1} \cdot \mathrm{h}^{-1}\right)$ e Clonidina

\section{DISCUSSÃO}

Os sintomas de abstinência alcoólica podem se iniciar após algumas horas da interrupção ou diminuição do consumo de álcool e podem ser classificados em leve (tremores), moderado (alucinações e sintomas simpáticos) e grave (febre, mudança no estado mental e alterações significantes dos sinais vitais). Os sintomas podem, em intervalo de tempo em torno de 72 horas, progredir para delirium tremens, condição clínica caracterizada por agitação grave, tremores, estado de confusão aguda, associados à desorientação, alucinações e hiperatividade autonômica, com duração, em média, menor 
do que sete dias, embora haja inúmeros casos com maior duração ${ }^{9}$. O delirium tremens, a mais grave manifestação da síndrome de abstinência alcoólica, ocorre aproximadamente em $5 \%$ dos pacientes hospitalizados com história de abuso de álcool e apresenta taxa de mortalidade de $15 \%{ }^{10}$. Uma vez constatado o abuso de álcool, a profilaxia adequada deve ser instituída com a manutenção dos níveis eletrolíticos normais, além da administração de tiamina, vitamina $B_{12}$ e ácido fólico associada à sedação apropriada.

Segundo a literatura, há evidências comprovando que os benzodiazepínicos são as drogas de escolha para o tratamento da síndrome de abstinência alcoólica e mesmo da sua complicação mais grave, o delirium tremens, pelo mecanismo de tolerância cruzada com o álcool, diminuindo a freqüência dos episódios de agitação, alucinações e tremores ${ }^{1,2}$. Entretanto, essa monoterapia não surte o efeito esperado em todos os pacientes. Necessita-se, assim, freqüentemente, do uso de drogas consideradas adjuvantes, como agonistas dos receptores $\alpha_{2}$-adrenérgicos, $\beta$-bloqueadores e carbamazepina. Existem alguns relatos de casos de resolução de delirium tremens, refratários aos benzodiazepínicos, com o emprego de propofol ${ }^{11}$.

O prolongado efeito do álcool sobre o número e a função dos receptores do sistema nervoso central causa excessiva excitabilidade nervosa central durante os períodos de abstinência, acarretando maior atividade noradrenérgica. A clonidina, um agonista $\alpha_{2}$-adrenérgico com seletividade de $200\left(\alpha_{2}\right)$ para $1\left(\alpha_{1}\right)$, ao reduzir a descarga de catecolaminas centrais, provavelmente no locus coeruleus, e inibir a exocitose de noradrenalina na fenda sináptica, permite o rearranjo do equilíbrio dos neurotransmissores, diminuindo os sintomas de abstinência $^{12}$. Dessa maneira, a clonidina melhora o padrão de sedação, pela ativação de receptores $\alpha_{2}$ centrais, porém pode provocar como complicação hipotensão arterial e bradicardia, devido à diminuição do efluxo simpático central associado à diminuição da liberação de noradrenalina pela ativação de receptores $\alpha_{2}$ pré-sinápticos periféricos ${ }^{13}$. Outra complicação do uso de clonidina, relatada na literatura, é a potencial relação entre uso de clonidina em altas doses no tratamento de delirium tremens associada à pseudo-obstrução aguda do cólon (síndrome de Ogilvie) ${ }^{14}$.

A grande maioria dos trabalhos demonstra que a clonidina pode ser utilizada como adjuvante associada aos benzodiazepínicos ${ }^{1,2,15}$ no tratamento de síndrome de abstinência alcoólica, por reduzir sua sintomatologia e gravidade ${ }^{6}$. No entanto, as evidências são inadequadas para determinar seus efeitos no delirium tremens ${ }^{2}$. Outros trabalhos relatam grande diminuição dos "escores" gerais da abstinência alcoólica em pacientes sob o uso de clonidina, porém com modesta ação nos sintomas alucinatórios quando comparados aos pacientes recebendo placebo ${ }^{12}$. A clonidina parece apresentar bons resultados também na prevenção da síndrome de abstinência. Demonstrou-se que $50 \%$ dos pacientes dependentes de álcool internados em hospital e que receberam placebo desenvolveram a síndrome, enquanto que no grupo de pacientes que recebeu clonidina durante a internação, apenas $9 \%$ apresentou sintomas da síndrome ${ }^{16}$.
No presente caso, a clonidina, utilizada a partir do $13^{\circ} \mathrm{dia}$, foi responsável, já nas primeiras horas após sua aplicação venosa inicial, por profunda e rápida diminuição do quadro de agitação psicomotora, dos tremores e da descarga adrenérgica, mostrando seu importante papel nesse tipo de sintomas, quando utilizada em associação com o propofol ou com o midazolam. O fato da dexmedetomidina, apesar de ter diminuído as doses de outros fármacos sedativos, não ter apresentado resposta tão eficiente como a da clonidina na resolução do quadro de agitação, já que possui maior especificidade aos receptores $\alpha_{2}$ em relação aos $\alpha_{1}$ (1600:1), não encontra resposta na literatura. Não encontramos pesquisas e nem relatos de casos com o uso da dexmedetomidina em pacientes com síndrome de abstinência ou delirium tremens. Um dos fatores que contribuem para o fato é que esse fármaco está disponível há pouco tempo no mercado. Uma possível resposta pode estar na ação da clonidina, um derivado imidazolínico, nos receptores imidazólicos centrais ${ }^{13}$.

A crise de abstinência do tabaco, caracterizada por irritabilidade, hostilidade, impaciência, ansiedade, agitação e dificuldade de concentração, pode ter se somado à síndrome de abstinência alcoólica no paciente. Pesquisas relatam que a clonidina é mais eficaz no tratamento da síndrome de abstinência do que a nicotina ${ }^{17}$. Outras pesquisas demonstram que, para cessação do hábito de fumar, os melhores resultados são obtidos com o uso de clonidina por via transdermal ${ }^{18}$. A cocaína, uma droga simpática estimulante, aumenta a liberação de noradrenalina pré-sináptica e bloqueia a sua recaptação ${ }^{19}$. Antes de realização de sedação em pacientes em estado com grande liberação simpática, é importante determinar a possibilidade de uso de cocaína e/ou procurar evidências de outras síndromes de abstinência. Benzodiazepínicos são habitualmente empregados em pacientes com suspeita ou certeza de uso de cocaína e, tanto $\alpha$ como $\beta$-bloqueadores podem ser utilizados. Os sintomas de abstinência tendem a serem opostos aos efeitos originais produzidos pelas drogas. Assim, os sintomas da abstinência por cocaína mais comuns são: depressão, ânsia, sonolência, cansaço, bradicardia e compulsão pela droga, o que nos leva a crer que no caso relatado o paciente não desenvolveu essa síndrome ou que esta tenha passado despercebida pela intensidade da síndrome de abstinência alcoólica apresentada pelo paciente.

Sinais e sintomas de abstinência por maconha são difíceis de serem determinados. De fato, poucos são os pacientes que necessitam de tratamento por abstinência ao uso de maconha. A síndrome de abstinência no homem foi descrita pela observação criteriosa de usuários que receberam doses regulares da droga por via oral e manifesta-se com irritabilidade, leve agitação, insônia e náuseas. Essa síndrome, entretanto, é somente observada em pessoas que utilizam grande quantidade de droga diariamente e que subitamente cessam seu consumo ${ }^{19}$.

O diagnóstico das síndromes de abstinência e mesmo do delirium tremens não é fácil de ser feito em Unidade de Terapia Intensiva, pois os pacientes estão em estado crítico e os sintomas, na maioria das vezes, podem ser mascarados pela 
utilização de drogas sedativas durante o emprego de ventilação artificial. Ressalta-se a importância da solicitação de informações aos familiares sobre o uso abusivo e freqüente de drogas, principalmente de álcool, para que se possam ser tomadas medidas profiláticas e mesmo iniciar-se o tratamento adequado o mais precocemente possível, abreviando-se o tempo total de internação e diminuindo os riscos dos pacientes. A clonidina, embora seja uma droga adjuvante, ganha cada vez mais espaço pela sua versatilidade em atuar em vários tipos de abstinência, entre elas a alcoólica, proporcionando sedação adequada com maior conforto e segurança aos pacientes e por ser um fármaco com excelente relação custo/benefício.

\section{Clonidine as Adjuvant Therapy for Alcohol Withdrawal Syndrome in Intensive Care Unit. Case Report}

Leandro Gobbo Braz, M.D.; Lais Helena Camacho Navarro, M.D.; José Reinaldo Cerqueira Braz, TSA, M.D.; Ubirajara Teixeira da Silva, M.D.; Fábio Akio Yamaguti, M.D.; José Carlos Cristovan, M.D.

\section{INTRODUCTION}

The universal goal of Intensive Care Units is to maintain adequate safety levels and comfort of severely ill patients when tracheal tubes are used to maintain artificial ventilation and when sedatives are needed. However, sedation of alcohol and other drugs abusers is a challenge, due to the high incidence of tolerance and withdrawal syndromes, closely related to post-surgical trauma and infection. Several approaches have been proposed for withdrawal syndromes, recommending both single drug therapy and the association of adjuvant drugs, such as clonidine, which seems to decrease sedation failures ${ }^{1,2}$.

Clonidine, an $\alpha_{2}$-adrenergic receptor agonist, is increasingly being used as adjuvant drug in general anesthesia and spinal blocks ${ }^{3}$. Its use outside the operating room is becoming popular, both for preanesthetic medication ${ }^{4}$ and for psychiatric disorders management, especially opioid ${ }^{5}$, alcohol ${ }^{6}$ or tobacco ${ }^{7}$ withdrawal syndromes, in addition to the possibility of being used in outpatient clinics to treat detoxification of such substances.

This report aimed at describing a case of a young alcohol and drug-dependent patient, admitted to the ICU after immediate postoperative complication, who developed alcohol withdrawal syndrome and tolerance to sedatives, only resolved after clonidine administration.

\section{CASE REPORT}

Male patient, 18 years old, alcohol, tobacco, cocaine and marijuana abuser, submitted to emergency enterectomy after fire- arm accident. During the immediate postoperative period, and in the ward, patient presented with respiratory depression after tracheal extubation. During tracheal re-intubation maneuvers, there has been gastric content aspiration. Patient was admitted to the ICU in the $1^{\text {st }}$ postoperative day, developing bilateral bronchopneumonia and pleural effusion, needing vasoactive drugs until the $4^{\text {th }}$ admission day to maintain hemodynamic parameters, and artificial ventilation until the $15^{\text {th }}$ day with high oxygen inspired fractions. Patient received adequate electrolytic replacement and thiamine, vitamin $B_{12}$ and folic acid throughout the admission period. There have been no acid-base or electrolytic balance disorders.

Initial sedation scheme was the association of 0.2 $\mathrm{mg} \cdot \mathrm{kg}^{-1} \cdot \mathrm{h}^{-1}$ midazolam and $3 \mu \mathrm{g} \cdot \mathrm{kg}^{-1} \cdot \mathrm{h}^{-1}$ fentanyl to reach level 4 or 5 in Ramsay's sedation scale ${ }^{8}$. As from the $4^{\text {th }}$ day, patient developed psychomotor agitation, shivering, tachycardia, arterial hypertension, sudoresis and mydriasis, requiring progressive drug dose increments but without symptoms improvement, even with the introduction of $4 \mathrm{mg} /$ day gastric lorazepam in the $6^{\text {th }}$ day. In the $9^{\text {th }}$ day, patient has received the highest doses: $0.28 \mathrm{mg} \cdot \mathrm{kg}^{-1} \cdot \mathrm{h}^{-1}$ midazolam, 4.13 $\mu \mathrm{g} \cdot \mathrm{kg}^{-1} \cdot \mathrm{h}^{-1}$ fentanyl and $16 \mathrm{mg} /$ day lorazepam, without agitation improvement.

In the $10^{\text {th }}$ day, 0.6 to $0.8 \mu \mathrm{g} \cdot \mathrm{kg}^{-1} \cdot \mathrm{h}^{-1}$ dexmedetomidine infusion was associated which, in the $11^{\text {th }}$ day and in the highest dose, has decreased other drug doses in $35 \%$ with partial symptoms improvement. In the $12^{\text {th }}$ day, midazolam and dexmedetomidine were replaced by $5 \mathrm{mg} \cdot \mathrm{kg}^{-1} \cdot \mathrm{h}^{-1}$ propofol infusion with mild worsening of symptoms. In the $13^{\text {th }}$ day, 0.15 mg intravenous clonidine every 6 hours was associated to the sedation scheme, with total resolution of psychomotor agitation, $38 \%$ decrease in propofol infusion and $42 \%$ decrease in fentanyl infusion as compared to the day before. In the $14^{\text {th }}$ day, fentanyl infusion was maintained while propofol was replaced by midazolam in doses $75 \%$ and $65 \%$ lower as compared to their peak doses in the $9^{\text {th }}$ day and patient remained adequately sedated (Ramsay 4 ). In the $15^{\text {th }}$ day, patient presented criteria for tracheal extubation and was discharged from the ICU, still under clonidine.

Sedation scheme is shown in figure 1.

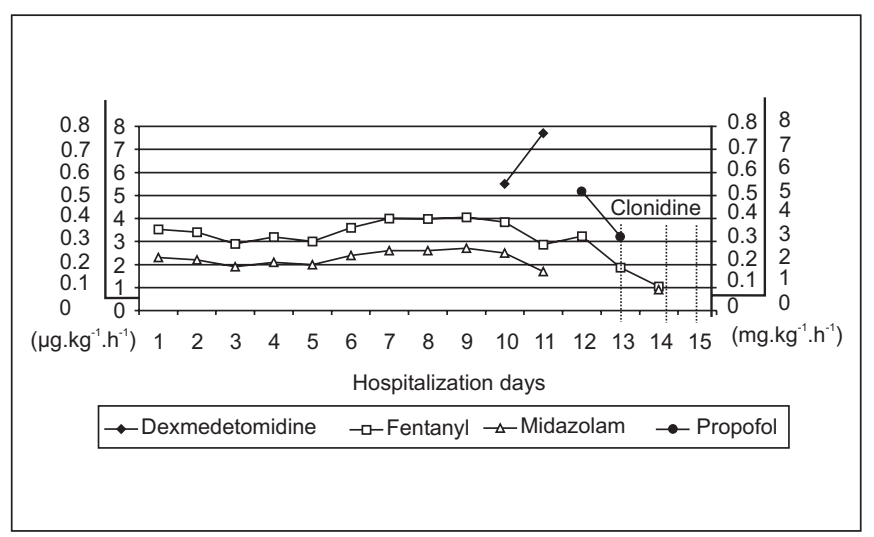

Figure 1 - Sedation Scheme Used during Hospitalization: Dexmedetomidine $\left(\mu \mathrm{g} \cdot \mathrm{kg}^{-1} \cdot \mathrm{h}^{-1}\right)$; Fentanyl $\left(\mu \mathrm{g} \cdot \mathrm{kg}^{-1} \cdot \mathrm{h}^{-1}\right)$; Midazolam $\left(\mathrm{mg} \cdot \mathrm{kg}^{-1} \cdot \mathrm{h}^{-1}\right) ;$ Propofol $\left(\mathrm{mg} \cdot \mathrm{kg}^{-1} \cdot \mathrm{h}^{-1}\right)$ and Clonidine 


\section{DISCUSSION}

Alcohol withdrawal syndrome symptoms may start few hours after alcohol consumption withdrawal or decrease and may be classified as mild (shivering), moderate (hallucinations and sympathetic symptoms) and severe (fever, mental status change and significant changes in vital signs). In approximately 72 hours, symptoms may progress to delirium tremens, clinical condition characterized by severe agitation, shivering and acute mental confusion, associated to disorientation, hallucinations and autonomic hyperactivity with mean duration of less than 7 days, although there are several cases with longer duration ${ }^{9}$. Delirium tremens, most severe alcohol withdrawal syndrome manifestation, is present in approximately $5 \%$ of patients admitted with past history of alcohol abuse, with $15 \%$ mortality rate ${ }^{10}$. Once alcohol abuse is confirmed, adequate prophylaxis should be instituted to maintain normal electrolytic levels, in addition to the administration of thiamine, vitamin $\mathrm{B}_{12}$ and folic acid associated to adequate sedation.

According to the literature, there are evidences that benzodiazepines are the drugs of choice to treat alcohol withdrawal syndrome and even its most severe complication, delirium tremens, for its mechanism of cross-tolerance with alcohol, decreasing the frequency of agitation, hallucination and shivering episodes ${ }^{1,2}$. This single drug therapy, however, does not have the expected effect in all patients. So, adjuvant drugs, such as $\alpha_{2}$-adrenergic receptor agonists, $\beta$-blockers and carbamazepine, are often needed. There are some reports on the resolution of delirium tremens refractory to benzodiazepines with propofol ${ }^{11}$.

The prolonged effect of alcohol on the number and function of central nervous system receptors determines excessive central nervous excitability during withdrawal periods, leading to higher noradrenergic activity. Clonidine, an $\alpha_{2}$-adrenergic agonist with selectivity of $200\left(\alpha_{2}\right)$ to $1\left(\alpha_{1}\right)$, in decreasing central catecholamines discharge probably in the locus coeruleus and inhibiting norepinephrine exocytosis in the synaptic cleft, allows for the rearrangement of neurotransmitters balance, decreasing withdrawal symptoms ${ }^{12}$. This way, clonidine improves sedation by activating $\alpha_{2}$ central receptors, but may cause arterial hypotension and bradycardia due to the decrease in central sympathetic efflux associated to norepinephrine release decrease by the activation of peripheral pre-synaptic $\alpha_{2}$-receptors ${ }^{13}$. Another clonidine complication reported in the literature is the potential relation of high clonidine doses to treat delirium tremens and colon acute pseudo-obstruction (Ogilvie's syndrome) ${ }^{14}$.

Most studies have shown that clonidine may be associated to benzodiazepines ${ }^{1,2,15}$ in the treatment of alcohol withdrawal syndrome to decrease symptoms and severity ${ }^{6}$. Evidences, however, are inadequate to determine its effects on delirium tremens ${ }^{2}$. Other studies have reported significant decrease in general alcohol withdrawal scores in patients under clonidine, however, with modest action in hallucination symptoms as compared to patients receiving placebo ${ }^{12}$. Clonidine seems to give good results also in the prevention of withdrawal syndromes. It has been shown that $50 \%$ of alcohol-dependent patients admitted to the hospital and receiving placebo have developed the syndrome, while in the group of patients receiving clonidine during admission, only $9 \%$ have developed the syndrome ${ }^{16}$.

In our case, clonidine administered as from the $13^{\text {th }}$ day, was responsible, already in the first hours after its initial intravenous administration, for deep and fast improvement in psychomotor agitation, shivering and adrenergic discharge, showing its important role in these types of symptoms, when used in association to propofol or midazolam. There is no explanation in the literature for the fact that dexmedetomidine, although having decreased the doses of other sedative drugs, has not shown such an effective response as compared to clonidine in the resolution of agitation, since it has more specificity for $\alpha_{2}$ receptors as compared to $\alpha_{1}(1600: 1)$. We have not found reports on the use of dexmedetomidine in withdrawal syndrome or delirium tremens patients. A contributing factor is that this drug was recently introduced in the market. A possible answer may be the action of clonidine, an imidazolinic derivative, on central imidazolic receptors ${ }^{13}$. Tobacco withdrawal syndrome, characterized by irritability, hostility, impatience, anxiety, agitation and difficult concentration, could have been added to alcohol withdrawal syndrome in this patient. Studies report that clonidine is more effective than nicotine to treat tobacco withdrawal syndrome ${ }^{17}$. Other studies have shown that, to quit smoking, the best results are obtained with transdermal clonidine ${ }^{18}$.

Cocaine, a stimulating sympathetic drug, increases pre-synaptic norepinephrine release and blocks its reuptake ${ }^{19}$. Before sedating patients with high sympathetic release, it is important to determine the possibility of the use of cocaine and/or look for evidences of other withdrawal syndromes. Benzodiazepines are normally used in patients with suspicion or certainty of cocaine abuse and both $\alpha$ and $\beta$-blockers may be used. Withdrawal symptoms tend to be opposed to original effects produced by the drugs. So, most common cocaine withdrawal symptoms are: depression, anxiety, somnolence, fatigue, bradycardia and drug compulsion, which lead us to believe that in our case patient has not developed this syndrome or that it went unnoticed due to the intensity of alcohol withdrawal symptoms presented by the patient. Marijuana withdrawal signs and symptoms are difficult to determine. In fact, there are few patients needing marijuana withdrawal treatment. Withdrawal syndrome in men was described by the thorough observation of users receiving regular oral doses of the drug and is manifested by irritability, mild agitation, insomnia and nausea. This syndrome, however, is only observed in people using large daily amounts of the drug and who suddenly interrupt its consumption ${ }^{19}$.

Withdrawal syndromes and even delirium tremens diagnoses are not easy in ICUs, because patients are critically ill and symptoms, most of the times, may be masked by sedatives during artificial ventilation. It is very important to ask relatives about abusive and frequent use of drugs, especially alcohol, for prophylactic measures to be taken and even start the ade- 
quate treatment as early as possible, thus decreasing total hospitalization time and minimizing patients risks. Clonidine, although being an adjuvant drug, is becoming increasingly popular for its versatility in acting on several types of withdrawals, among them alcohol withdrawal, allowing adequate sedation with better comfort and safety for patients, and for being a drug with excellent cost/benefit ratio.

\section{REFERÊNCIAS - REFERENCES}

01. Robinson BJ, Robinson GM, Maling TJ et al - Is clonidine useful in treatment of alcohol withdrawal?. Alcoholism: Clinical \& Experimental Research,1989;13:95-98.

02. Moyo-Smith MF - Pharmacological management of alcohol withdrawal. A meta analysis and evidence based practice guideline. JAMA, 1997;278:144-151.

03. Braz JRC, Koguti ES, Braz LG et al - Efeitos da Associação da Clonidina à Bupivacaína Hiperbárica na Anestesia Subaracnóidea Alta. Rev Bras Anestesiol, 2003;53:561-572.

04. Braz LG, Vianna PTG, Braz JRC et al - Níveis de sedação determinados pela clonidina e midazolam na medicação pré-anestésica. Avaliação clínica e eletroencefalográfica bispectral. Rev Bras Anestesiol, 2002;52:9-18.

05. Kahn A, Munford JP - Double-blind study of lofexedine and clonidine in the detoxification of opiate addicts in hospital. Drug\&Alcohol Dependence, 1997;44:57-61.

06. Bjorkqvist SE - Clonidine in alcohol withdrawal. Acta Psych Scand, 1975;52:256-263.

07. Davison R, Kaplan K, Fintel D et al - The effect of clonidine on the cessation of cigarettes smoking. Clin Pharmacol, 1988;44: 265.

08. Ramsay MAE, Savege TM, Simpson BRJ et al - Controlled sedation with alphaxalene-alphadolone. $\mathrm{Br}$ Med J, 1974;2: 656-659.

09. Wolf KM, Shaughness AF, Middleton DB - Prolonged delirium tremens requiring massive doses of medication. J Am Board Farm Pract, 1993;6:502-504.

10. Cohen IL, Gallagher TJ, Pohlman AS - Management of the agitated intensive care unit patient. Crit Care Med, 2002;30: 97-123.

11. McCowan C, Marik P - Refractory delirium tremens treated with propofol. A case series. Crit Care Med, 2000;28:1781-1784.

12. Cusman Jr P - Clonidine and alcohol withdrawal. Advances Alcohol\&SubstanceAbuse, 1987;7:17-28.

13. Reis DJ, Regunanthan S, Meeley MP - Imidazole receptor and clonidine displacing sustance in the relationship to control blood pressure, neuroprotection and adrenomedullary secretion. Am J Hipertens, 1992;5:51-57.

14. Stieger DS, Cantieni R, Frutiger A-Acute colonic pseudobstruction in two patients receiving high dose clonidine for delirium tremens. Intens Care Med, 1997;23:780-782.

15. Spies CD, Rommelspacher $\mathrm{H}$ - Alcohol withdrawal in the surgical patient prevention and treatment. Anesth Analg, 1999;88: 946-954.
16. Mondavio M, Ghizza GF - Use of clonidine in the prevention of alcohol withdrawal syndrome. Minerva Medica, 1989;80: 1233-1235.

17. Aparici M, Fernandez AL, Alegria E - Clonidine in the treatment of tobacco withdrawal. A comparison with nicotine chewing gum. Rev Clin Esp, 1994;194:453-456.

18. Gourlay SG, Stead LF, Benowitz NL - Clonidine for smoking cessation. Cochrane Database of Systematic Reviews, 2000; CD;000058.

19. Cousin DB - Clinical practice guidelines for the sustained use of sedatives and analgesics in the critically ill adult. Crit Care Med, 2002;30:119-141.

\section{RESUMEN}

Braz LG, Navarro LHC, Braz JRC, Silva UT, Yamaguti FA, Cristovan JC - Clonidina como Droga Coadyuvante en el Tratamiento de la Síndrome de Abstinencia Alcohólica en Unidad de Terapia Intensiva. Relato de un Caso

JUSTIFICATIVA Y OBJETIVOS: La sedación de dependientes de alcohol y drogas en Unidades de Terapia Intensiva (UTI) es un desafío por la elevada incidencia de tolerancia a las drogas sedativas y de la elevada frecuencia de síndromes de abstinencia. El objetivo de este relato es mostrar un caso de un paciente joven admitido en la UTI que desarrolló síndrome de abstinencia alcohólica y tolerancia a las drogas sedativas, solucionadas solamente después del uso de clonidina.

RELATO DEL CASO: Paciente del sexo masculino, 18 años, dependiente de alcohol, tabaco, cocaína y mariguana, víctima de accidente por arma de fuego, fue admitido en la UTI en el $1^{\circ}$ día de post-operatorio de enterectomía, después de aspiración de contenido gástrico durante reintubación traqueal. Evolución clínica: drogas vasoactivas hasta el $4^{\circ}$ día de internación y broncopneumonia bilateral con derrame pleural y necesidad de ventilación artificial hasta el $15^{\circ}$ día. El esquema de sedación inicial utilizado fue la asociación de midazolan y fentanil. A partir del $4^{\circ}$ día, el paciente presentó varios episodios de agitación psicomotora, mismo con la asociación de loracepam en el $6^{\circ}$ día. En el $9^{\circ}$ día, el paciente recibió las mayores dosis de los fármacos, más permanecía agitado. Se optó por la asociación de dexmedetomidina, que redujo las dosis de las otras drogas en $35 \%$ y diminuyó la agitación. En el $12^{\circ}$ día, el midazolan y la dexmedetomidina fueron substituidos por la infusión de propofol, con empeoramiento del cuadro. En el $13^{\circ}$ día, fue asociada clonidina al esquema de sedación, con resolución del cuadro de agitación. En el $14^{\circ}$ día, el propofol fue suspenso, siendo mantenida la infusión de fentanil y reintroducida la infusión de midazolan, con dosis respectivamente $75 \%$ y $65 \%$ menores en relación al pico de uso de estas drogas. En el $15^{\circ}$ día, el paciente fue extubado y tuvo alta de la UTI.

CONCLUSIONES: La droga escogida para el tratamiento del síndrome de abstinencia alcohólico es el benzodiazepínico. No obstante, en el presente relato, solamente el uso coadyuvante de clonidina consiguió proporcionar tratamiento adecuado al paciente. 